\title{
BOHATER, DONOSICIEL, KOZIOŁ OFIARNY. ROZWAŻANIA O SYGNALISTACH I SPOŁECZNEJ ROLI WHISTLEBLOWINGU
}

\author{
Aleksandra Kobylińska \\ Instytut Spraw Publicznych
}

Whistleblowing ${ }^{1}$ to działanie polegające na ujawnieniu przez pracownika - lub osobę w inny sposób ściśle związaną z daną instytucją - nieprawidłowości, do jakich dochodzi w organizacji, które są istotne z punktu widzenia interesu publicznego. Termin whistleblowing został ukuty w latach 70. przez Ralpha Nadera, amerykańskiego polityka i działacza społecznego. Pragnął on zwrócić uwagę na rolę jednostek, dzięki którym opinia publiczna dowiadywała się o nadużyciach w wielkich amerykańskich koncernach (Wright 2008). Whistleblowing można dosłownie przetłumaczyć jako gwizdanie, dmuchnięcie w gwizdek. Do czego konkretnie nawiązuje to określenie w tej kwestii różni autorzy przedstawiają odmienne interpretacje. Anna Lewicka-Strzałecka (2012) sugeruje, że whistleblowing to analogia do sposobu przywoływania pomocy stosowanego dawniej przez policjantów, którzy za pomoca gwizdków sprowadzali posiłki w sytuacji niebezpieczeństwa. Whistleblower w tym ujęciu to ktoś, kto wszczyna alarm, aby zwrócić uwagę otoczenia na jakąś niepokojącą sytuację - co wydaje się trafnie oddawać współczesne znaczenie tego pojęcia. Z kolei zdaniem Richarda Swedberga (1999) chodzi raczej o porównanie do interwencji sędziego podczas meczu piłkarskiego, gdy dochodzi do sytuacji łamania reguł gry. Autor sam jednak przyznaje, że taka analogia może być zwodnicza, ponieważ sugeruje, że gwiżdżący dysponuje jakaśs szczególną władzą czy uprzywilejowaną pozycja.

\footnotetext{
${ }^{1} \mathrm{~W}$ języku polskim nie upowszechnił się jeszcze żaden odpowiednik wyrazu whistleblowing. Termin whistleblower doczekał się jednak swoich polskich odpowiedników, spośród których najbardziej powszechnie stosowany jest „sygnalista”; w dalszej części tekstu będzie on wykorzystywany wymiennie $\mathrm{z}$ angielskim pierwowzorem.
} 
Jakie dokładnie sytuacje możemy zakwalifikować jako whistleblowing? Nie ma w tej kwestii jednolitego stanowiska wśród naukowców, badaczy, prawników czy ekspertów z dziedziny zarządzania. Spory toczą się m.in. wokół tego, czy należy brać pod uwagę motywy sygnalisty oraz czy whistleblowing odnosi się tylko do zgłoszenia nieprawidłowości zewnętrznej instytucji, czy można tym terminem określać również informowanie w ramach kanałów wewnątrzorganizacyjnych, a także - czy za sygnalistę można uznać również osobę, na której spoczywal prawny obowiązek zawiadomienia o nieprawidłowościach (Jubb 1999).

$\mathrm{Z}$ naszego punktu widzenia istotne są następujące kryteria: sygnalistą musi być osoba, która z racji swojej pozycji ma dostęp do wiedzy wewnętrznej na temat organizacji i jest z nią związana więzami lojalności - czyli pracownik etatowy albo osoba współpracująca z instytucją na mocy stosunku cywilnoprawnego, stażysta, wolontariusz, pracownik tymczasowy czy były pracownik (Worth 2013). Sygnalista ujawnia nadużycia, do jakich dochodzi w obrębie instytucji - może to robić zarówno w ramach jej własnych struktur, jak i wobec podmiotu zewnętrznego. Nieprawidłowości, o których alarmuje, muszą być ważne z punktu widzenia interesu publicznego. Jest to dość pojemna kategoria, którą czasem próbuje się dookreślać, tworząc katalogi istotnych nadużyć. Przykładowo Transparency International w swojej definicji wymienia praktyki o charakterze przestępczym lub korupcyjnym, sytuacje zagrożenia zdrowia lub bezpieczeństwa publicznego czy środowiska naturalnego, nadużycie uprawnień, nieuprawnione wykorzystanie lub marnotrawstwo środków publicznych oraz konflikt interesów (Worth 2013). Wreszcie bardzo ważnym aspektem whistleblowingu jest nierównorzędność stron - sygnalista zawsze dysponuje mniejszą siłą i zasobami finansowymi niż instytucja, co stawia go w bardzo trudnej sytuacji.

Whistleblowing jest przedmiotem różnych studiów i analiz, pozostaje jednak przede wszystkim w obszarze zainteresowania nauk o zarządzaniu, etyki biznesu czy prawa. Próby badania czy refleksji nad tym zjawiskiem na gruncie socjologii należą do rzadkości. Niewielkie zainteresowanie whistleblowingiem ze strony badaczy życia społecznego jest zastanawiające. Wpisuje się ono w trend zaobserwowany jeszcze w latach 70. przez Jerzego Kwaśniewskiego i Jacka Kurczewskiego. Pisząc o potrzebie pogłębiania wiedzy o „szczególnie cennych zjawiskach w życiu społecznym” - do których zaliczali m.in. działania ludzi podejmujących w interesie społecznym interwencje w różnych sprawach poprzez instytucje, prasę czy radio - autorzy zauważyli: „Budzi wprost zdziwienie, dlaczego wyszukiwanie, badanie i uogólnianie wyników badań nad takimi zjawiskami jest przedmiotem 
tak małego zainteresowania w naukach społecznych" (cyt. za Kurczewski 2013: 29). Whistleblowing wydaje się nie tylko bardzo ciekawym, ale też wyjątkowo istotnym zagadnieniem, które skupia w sobie szereg ważkich socjologicznych problemów, takich jak: napięcie między rzeczywistością społeczną a sferą działań jednostki, rola odwagi cywilnej w organizacji czy sytuacja osób, które znalazły się na marginesie życia społecznego (Wright 2008: 2).

\section{/// Istota i społeczne znaczenie whistleblowingu}

Proces stawania się sygnalistą poprzedzony jest zdobyciem informacji o nadużyciach, do jakich dochodzi w organizacji. Dzieje się to w różnych okolicznościach - pracownik może natrafić na dokumenty świadczące o nieprawidłowościach, może być mimowolnym świadkiem patologicznej sytuacji lub zostać wprost zaproszonym do przestępczego procederu. Osoba, która dopatrzy się nadużyć, staje przed bardzo poważnym dylematem: czy pozwolić na to, by nieprawidłowości trwały, czy interweniować, narażając się na trudne do przewidzenia konsekwencje. Jeśli zdecyduje się przekazać informację właściwym organom wewnątrz organizacji albo instytucji zewnętrznej - staje się sygnalista. Jak pokazują doświadczenia polskich i zagranicznych whistleblowers (Kobylińska, Folta 2015, Alford 2002), podjęcie interwencji w wielu przypadkach prowadzi do bardzo gwałtownej negatywnej reakcji organizacji, która na różne sposoby stara się uciszyć, zdyskredytować czy wyeliminować „posłańca złej nowiny”. Schemat reakcji zależy w dużej mierze od ogólnych standardów etycznych panujących w danej instytucji. W niektórych organizacjach tworzy się wyspecjalizowaną infrastrukturę etyczną nastawioną na wychwytywanie sygnałów o nieprawidłowościach. Pracownicy są tam zachęcani do zgłaszania nadużyć m.in. poprzez tworzenie bezpiecznych kanałów informowania, które maja minimalizować osobiste ryzyko pracownika decydującego się ujawnić nieprawidłowości.

Ze względu na specyfikę zjawiska bardzo trudno oszacować skalę whistleblowingu. Na podstawie dostępnych danych można jednak stwierdzić, że odgrywa ono ważną rolę w zwalczaniu nieprawidłowości w firmach i instytucjach. Świadczyć mogą o tym chociażby wyniki dorocznych badań Global Economic Survey prowadzonych przez firmę PwC (2014), które wskazuja whistleblowing jako jedno z najważniejszych narzędzi wykrywania nadużyć w korporacjach. W 2014 roku 23\% badanych przypadków nieprawidłowości w firmach na całym świecie zostało wykrytych dzięki informacjom po- 
chodzącym od pracowników, a w badaniach z poprzednich lat ten odsetek był jeszcze wyższy i wynosił 43\% (PwC 2007).

Sygnały pochodzące od pracowników pełnią istotną funkcję nie tylko w samooczyszczeniu organizacji, ale także w zwalczaniu patologii istotnych z punktu widzenia dobra publicznego. Bez aktywności osób dysponujących wewnętrzną wiedzą na temat działań instytucji opinia publiczna nie miałaby szansy dowiedzieć się o wielu nadużyciach zagrażających ważnym interesom społecznym (Calland, Dehn 2004).

\section{/// Sygnalista jako laicki święty}

Whistleblowing w Polsce wciąż jeszcze pozostaje zjawiskiem bardzo słabo kojarzonym i rozpoznanym. Po pierwsze, samo pojęcie jest dla większości Polaków niezrozumiałe. Tematem interesuje się dość wąskie grono specjalistów, działających najczęściej na polu nauk o zarządzaniu czy ekonomii, więc nie zaistniał on jak dotąd szerzej w społecznej świadomości. Postać osoby ujawniającej patologie obecne w zakładzie pracy wciąż w odbiorze społecznym budzi skojarzenia z donosicielstwem i cieszy się tym samym ograniczonym zaufaniem.

Nieco inaczej rzecz się ma w Stanach Zjednoczonych, gdzie sygnaliści stali się ważnymi postaciami życia publicznego, a niekiedy funkcjonują wręcz jako ikony popkultury. Wynika to niewattpliwie z ukształtowanej już świadomości problemu oraz tego, że whistleblowers służą jako symbol walki z patologiami korporacyjnych i rządowych struktur.

Jak podkreślają różni autorzy (Alford 2002, Grant 2002, Wright 2008), w amerykańskim popularnym dyskursie dominuje wizerunek sygnalisty jako samotnego bohatera, mężnego człowieka sumienia, który walczy o prawdę i sprawiedliwość z potęgą cynicznych korporacji albo skorumpowanego państwa, i odnosi ostatecznie zwycięstwo (jeśli nie faktyczne, to przynajmniej moralne). Colin Grant zauważa wręcz, że whistleblowers urastają w Ameryce do rangi laickich świętych (Grant 2002). Obraz ten jest wzmacniany przez popkulturę, która karmi masową wyobraźnię produkcjami filmowymi powstałymi w oparciu o najbardziej spektakularne historie sygnalistów, np.: Serpico - film z Alem Pacino w roli głównej, opowiadający o funkcjonariuszu nowojorskiej policji odkrywającym praktyki korupcyjne wewnątrz tej formacji, Silkwood z Meryl Streep o pracowniczce reaktora jądrowego, która demaskuje panujące tam patologie, Niewygodna prawda - produkcja opowiadająca o funkcjonariuszce sił pokojowych w Bośni, która ujawnia proceder handlu kobietami, czy Wierny ogrodnik - opo- 
wieść o sygnalistach alarmujących o nieetycznych działaniach koncernów farmaceutycznych w Afryce. Rzeczywistość jest jednak znacznie bardziej złożona - co pokazują dane empiryczne z różnych części świata. Sygnaliści nie tylko odstają często od uproszczonego, heroicznego obrazu. Musza też najczęściej zapłacić bardzo wysoką cenę za swoją aktywność, a zamiast uznania i wsparcia doświadczają agresji, izolacji albo obojętności (Alford 2002, Wright 2008).

\section{/// Kluczowe problemy związane $\mathrm{z}$ whistleblowingiem}

Istotą dylematów związanych z whistleblowingiem jest fakt, że wciąz pozostaje on zjawiskiem bardzo niejednoznacznie ocenianym (zwłaszcza wtedy, gdy wiąże się z przekazywaniem informacji o nieprawidłowościach podmiotowi zewnętrznemu). U jego podłoża leży bowiem fundamentalny konflikt wartości (Elliston 1982). Z jednej strony, pracownik jest zobowiązany do lojalności wobec organizacji i współpracowników, nieujawniania tajemnic wewnętrznych i dbania o wizerunek instytucji. Z drugiej strony, staje on wobec sytuacji zagrożenia jakiegoś istotnego dobra, w której często jedynym rozwiązaniem jest przekazanie sygnału o nieprawidłowościach komuś z zewnątrz. Nie wszyscy jednak w równym stopniu odczuwają to napięcie. Najbardziej typową reakcja na nadużycia są konformizm i bierność, racjonalizowane na różne sposoby (Calland, Dehn 2004).

W organizacji, w której dochodzi do nieprawidłowości, a milcząca większość przechodzi nad tym do porządku dziennego, wytwarza się specyficzny stan równowagi. Z tego powodu interwencja sygnalisty może doprowadzić do bardzo gwałtownej reakcji grupy, nie tylko osób bezpośrednio odpowiedzialnych za nadużycia, ale także biernej większości.

Charles Fred Alford w książce o znamiennym tytule Whistleblowers Broken Lives and Institutional Power (2001) ilustruje, jak dramatyczne konsekwencje ponoszą osoby demaskujące nadużycia, nawet w Stanach Zjednoczonych, gdzie funkcjonują najbardziej rozwinięte instytucjonalne mechanizmy ochrony whistleblowers na świecie. Autor trafnie pokazuje, że reakcje grupy, z jakimi spotykają się pracownicy ujawniający patologie organizacji, noszą znamiona opisanego przez René Girarda mechanizmu kozła ofiarnego. Sygnalista, który poprzez swoją aktywność prowadzi do zachwiania obowiązującego porządku w grupie, często doświadcza z jej strony zbiorowej przemocy symbolicznej, która ma ostatecznie doprowadzić do izolacji i wykluczenia ofiary. Alford przytacza liczne przykłady whistleblowers, którzy na skutek swojej aktywności trafili „na pustynię” - znaleźli się na mar- 
ginesie życia społecznego, zawodowego, rozpadło im się życie rodzinne. De Maria (1997) wskazuje z kolei na podobieństwo środków odwetowych stosowanych wobec sygnalistów do vendetty - rytualnej zemsty środowisk mafijnych. Z tego powodu zdaniem Granta whistleblowing to w wielu sytuacjach działanie wręcz straceńcze i lekkomyślne (moral foolishness). Trudno więc się dziwić, że wielu sygnalistów dochodzi do gorzkiej konkluzji, że gdyby wiedzieli, co ich czeka, nie zdecydowaliby się na tak daleko idące poświęcenie (Alford 2001).

\section{/// Społeczno-psychologiczne uwarunkowania whistleblowingu}

Dlaczego więc niektóre jednostki decyduja się na działanie obarczone tak poważnym ryzykiem? Idąc tropem rozważań Roberta Kinga Mertona zawartych w klasycznej pracy Teoria socjologiczna i struktura społeczna, można zacząć od dość oczywistej obserwacji, że w każdej społeczności funkcjonują osoby, których postawy i zachowania nie wpisuja się w typowy schemat obowiązujący w danej grupie. Charakteryzując postawy nonkonformistyczne, Merton podkreśla, że należą one do sfery dewiacji, trzeba je jednak wyraźnie odróżnić od innych przejawów zachowań wykraczających poza ustalony porządek. Nonkonformista i przestępca są do siebie podobni przede wszystkim w tym, że nie spełniaja „,normatywnych oczekiwań innych ludzi, z którymi współdziałają w systemie wzajem powiązanych statusów społecznych i ról” (Merton 2002: 403). Różni ich jednak bardzo wiele - w przeciwieństwie do przestępcy nonkonformista występuje z otwartą przyłbica, kwestionuje obowiązujące w danej grupie normy i dąży do ich zmiany, a także działa w imię „wyższych zasad moralnych”, podczas gdy kryminalista jest przede wszystkim nastawiony na realizację własnych interesów, bez ambicji zmiany społecznych reguł, które narusza.

Nonkonformizm jednostki ${ }^{2}$ nie polega jednak wyłącznie na odrzuceniu zastanych norm. Wykorzystując teorię grup odniesienia, Merton interpretuje zachowanie nonkonformistyczne jako wybór innej grupy odniesienia, niż jest to przyjęte w głównym nurcie życia społecznego. Wykorzystuje w tym celu obrazowy cytat z Colleya, który pisał: „ten, kto - jak się wydaje - nie dotrzymuje kroku reszcie pochodu, w rzeczywistości idzie w takt innej muzyki, [...] słyszy innego dobosza" (Merton 2002: 401). Postawa

\footnotetext{
${ }^{2}$ Rozważania te odnoszą się do typu nonkonformizmu nazwanego przez autora „publicznym”. Nonkonformizm całkowicie "prywatny” jest, zdaniem autora, działaniem o charakterze wyłącznie ,autystycznym”, „mającym niewiele wspólnego z rzeczywistością zewnętrzną” (Merton 2002: 402-403).
} 
nonkonformistyczna nie jest więc czysto indywidualistyczna, ale polega na wyborze bardziej odlegtych zależności. Nonkonformista znajduje się więc w innym układzie odniesienia, a jego postawa niesie w sobie potencjał modyfikowania ustalonych wzorów postępowania w grupie. Zachowanie nonkonformistyczne uaktywnia jednak zarazem mechanizmy kontroli społecznej, które dążą do przywołania odstępcy do porządku. Reakcje grupy potrafią być naprawdę daleko idące, co dobitnie pokazują losy sygnalistów.

W kontekście whistleblowers warto także przywołać pozostałe koncepcje teoretyczne dotyczace roli postaw nadnormalnych w życiu społecznym. Można tu wspomnieć o innej klasycznej pozycji literatury socjologicznej - Ludzie teraźniejsi a cywilizacja przysz̨ości Floriana Znanieckiego. Autor wskazuje, jak doniosłą rolę w życiu społecznym i w rozwoju cywilizacji odgrywaja „zboczeńcy” - osoby, które przez swoją wybitność i niezależność przyczyniają się do kształtowania nowego porządku społecznego, kulturowego czy politycznego (Znaniecki 2001).

Istotnym głosem - który pomaga wyjaśnić rolę sygnalistów w życiu społecznym - jest także koncepcja dewiacji pozytywnej Jerzego Kwaśniewskiego (Kwaśniewski 1976). Autor zwrócił uwagę na rolę odgrywaną przez jednostki, które gotowe są poświęcić swoje interesy, energię, pomysłowość lub narazić zdrowie albo życie dla dobra innych. Przykładem takiego pozytywnego dewianta jest m.in. osoba, która „samotnie, lecz konsekwentnie przeciwstawia się w interesie społecznym nadużyciom czy korupcji w swym zakładzie pracy, nie zważając na groźby i prowokacje ze strony kliki, jak również na perswazje ze strony kolegów, którzy tylko «po cichu» akceptuja jego zachowania” (Kwaśniewski 1976: 215). Istota pozytywnej dewiacji jest przede wszystkim to, że działanie tego rodzaju przekracza standardowe oczekiwania społeczne. Autor trafnie zauważa, że niejednokrotnie - mimo obiektywnie pozytywnych skutków społecznych takiej postawy - nie spotyka się ona jednak z przychylną reakcją otoczenia.

\section{/// Sygnaliści w Polsce}

Zjawisko whistleblowingu w Polsce nie zostało jak dotąd kompleksowo zbadane. Pewnych wyrywkowych informacji dostarczają wnioski z monitoringu przeprowadzonego przez badaczy z Instytutu Spraw Publicznych ${ }^{3}$ na

\footnotetext{
${ }^{3}$ Przypadki dobrano tak, aby dawały możliwie zróżnicowany obraz zjawiska ze względu na typ instytucji, w jakiej występuje. Do badanych docierano poprzez kompetentnych informatorów (dziennikarzy, działaczy społecznych), analizę materiałów prasowych i internetowych, bezpośrednie zgłoszenia sygnalistów oraz metodą kuli śniegowej. Do analizy treści wywiadów pogłębionych wykorzystano oprogramowanie Atlas TI. Pełne omówienie materiału zostało zawarte w publikacji:
} 
przełomie 2013 i 2014 roku, w ramach którego przeanalizowano szczegółowo 12 przypadków sygnalizowania nieprawidłowości - przeprowadzono wywiady pogłębione $z$ sygnalistami, zbadano dokumenty i relacje prasowe dotyczące wybranych spraw. Na podstawie zgromadzonego materiału nie można co prawda formułować jakichkolwiek definitywnych opinii, jednak dostarczają one intuicji na temat sytuacji polskich sygnalistów.

Przebadane przypadki miały miejsce w różnych typach instytucji, od administracji centralnej, przez instytucje samorządowe, służby mundurowe, uczelnie wyższe, służbę zdrowia, po przedsiębiorstwa prywatne i sektor pozarządowy. Zgłaszane nadużycia dotyczyły zarówno problemów bardziej powszednich (łamanie praw pracowniczych, mobbing, plagiat w środowisku profesorskim), jak i poważniejszych patologii, takich jak: korupcja przy przetargu, fałszerstwa w badaniach klinicznych nad lekami, nieuzasadnione stosowanie inwazyjnej procedury medycznej w celu uzyskania wyższego dofinansowania z NFZ czy usiłowanie gwałtu na jednej z pracownic.

Na podstawie przeanalizowanych doświadczeń polskich sygnalistów można zauważyć, że w instytucjach i firmach często brakuje woli do tego, by aktywnie walczyć $z$ nadużyciami. Sygnaliści, którzy pierwsze kroki kierowali przeważnie do swoich przełożonych wewnątrz organizacji, przekonywali się szybko, że organizacja nie jest zdolna do podjęcia skutecznych działań naprawczych. Zanim to nastapiło, niektórzy nie spodziewali się, że przyjdzie im odegrać rolę samotnych bohaterów, którzy muszą się bronić przed ciosami ze strony dużo potężniejszego przeciwnika.

Osoby, które zdecydowały się zgłosić zaobserwowane nadużycia, odwoływały się do różnych motywacji. Byłoby zdecydowanie zbyt dużym uproszczeniem utożsamiać każdego sygnalistę z opisywanym przez Kwaśniewskiego pozytywnym dewiantem - jednak niewatpliwie były w tym gronie osoby, których pobudki miały od początku charakter fundamentalny.

Policjant, który podjął kroki, aby stanąc w obronie kolegi będącego ofiarą mobbingu ze strony przełożonego, tak mówił o swoich motywach:

Ale wybrałem drogę prawdy [...]. Bo też żona mi mówiła: „Czy ci to było potrzebne?”. Ale tak zostałem wychowany, że nie mogłem się pogodzić z taką nieprawidłowością. [...] [J]ak ja bym się wewnętrznie czuł, że nie odważyłem się powiedzieć prawdy [W16]?

Sygnaliści-ludzie, którzy nie potrafia milczeć. Doświadczenia osób ujawniajacych nieprawidtowości w instytucjach i firmach $w$ Polsce (Kobylińska, Folta 2015). 
Pracownica urzędu skarbowego, która aktywnie protestowała przeciwko wydaniu niezgodnej z prawem, a korzystnej dla lokalnego polityka, decyzji podatkowej, odwoływała się z kolei do swojego poczucia sprawiedliwości:

No, ja komentowałam to głośno w pokoju, mówiłam, że to jest nie w porządku i w ogóle, może wszystkich tak będziemy rozliczać, dlaczego biedni maja płacić podatki, a bogaci nie. Bo w końcu to jest naprawdę nieuczciwe [W02].

Kobieta, która ujawniła sprawę ustawionego przetargu, deklarowała z kolei, że postąpiła w imię przyzwoitości i z pobudek patriotycznych, argumentując, że to ostatecznie całe społeczeństwo płaci za nadużycia finansowe w instytucjach publicznych. Dla osób, które były świadkami łamania praw pracowniczych, w tym mobbingu, impulsem do interwencji była empatia wobec ofiar tych praktyk. Część badanych nie kryła jednak, że motorem ich działania było także częściowo poczucie niechęci wobec nielubianego zwierzchnika albo też obawy, że milczące współuczestnictwo w nielegalnych praktykach może mieć w przyszłości negatywne konsekwencje:

I zaczęłam po prostu sobie uświadamiać, że te wszystkie nieprawidłowości, które ja zgłaszałam, będą chcieli przypisać mojej osobie. Że jeśli ja tego dalej nie zgłoszę, czyli jakiemuś organowi zewnętrznemu, kontrolnemu jakiemuś, to wszystkie te rzeczy przypiszą mojej osobie - a bo księgowa na to pozwoliła, mimo że miałam tego przełożonego, głównego księgowego, który tak naprawdę powinien być za to sam odpowiedzialny [...] [W7].

Trzeba podkreślić, że nawet osoby zgłaszające nieprawidłowości pod wpływem bardziej przyziemnych czy pragmatycznych pobudek, musiały się ostatecznie wykazać dużą dozą nonkonformizmu i niezłomności w obliczu przykrych, a niekiedy dramatycznych konsekwencji, które spotykały je w odpowiedzi na podjęcie interwencji.

Część sygnalistów autentycznie wierzyła w to, że poinformowani przez nich zwierzchnicy będa zainteresowani rozwiązaniem problemu. Ci jednak z wielu względów nie byli zainteresowani aktywnym zajęciem się sprawą. Odważna i bezkompromisowa postawa sygnalistów wprawiała niektórych zwierzchników w konsternację. Jedna z sygnalistek, która zgromadziła do- 
wody na bardzo poważne nieprawidłowości związane z wyprowadzaniem majątku przedsiębiorstw publicznych, tak opisywała reakcję swojego przełożonego:

Widziałam strapienie tego człowieka coraz większe. [...] Powiedział wprost: „Ja mam niecałe dwa lata do emerytury i ja głowy nie nadstawię, żeby to ratować. Nie nadstawię" [W12].

Zgłoszenie nieprawidłowości, nawet dokonane wyłącznie na forum wewnętrznym, uruchamiało proces piętnowania sygnalistów na różne sposoby. Przełożeni odsuwali ich od odpowiedzialnych zadań, starali się na różne sposoby ich zastraszyć, zdyskredytować czy odebrać im wiarygodność. Niektóre przykłady takich działań bardzo wymownie wpisywały się w mechanizm kozła ofiarnego.

Jedna z sygnalistek opisywała m.in. publiczne połajanki organizowane przez jednego ze zwierzchników:

Ta osoba, nazwijmy go „szara eminencja”, urządzała takie spotkania u dyrektora, żeby mnie skompromitować. [...] [J]eżeli ktoś już w sposób grubiański mnie po prostu ośmiesza, to na to nie ma obrony. Bo ja mogę, jeżeli ktoś mi merytorycznie zarzuca coś, to ja się mogę, prawda, obronić, ale jeżeli ktoś mnie znieważa, to nie ma obrony [W12].

Inna osoba boleśnie doświadczyła nie tylko wrogości ze strony kierownictwa, ale też agresji ze strony współpracowników:

W momencie, gdy ta sprawa, gdy to już było dla wszystkich jasne, że zostanie umorzona, stałam się po prostu trędowata. Nikt się do mnie nie odzywał, nikt mi nie odpowiadał „dzień dobry”, zdarzały się na korytarzu gesty, że na przykład koleżanka pluła mi na buty, tylko tak w cudzysłowie, bez śliny, po prostu wykonywała tego typu gest. Chodziło o to, że im bardziej się ode mnie odetną, tym większą szansę mają pozostać w pracy z tym szefem, który robił to, co robił. Ludziom zależy na pieniądzach [W11].

Niektórzy pracodawcy na różne sposoby starali się oddziaływać na otoczenie zawodowe sygnalisty, aby doprowadzić od jego izolacji, propo- 
nując m.in. gratyfikacje finansowe osobom, które potwierdzą ich wersję wydarzeń w postępowaniu sądowym.

Organizacje podejmowały także próby zdyskredytowania sygnalistów poprzez psucie opinii w środowisku zawodowym i gromadzenie na nich tzw. haków. Przeciwko policjantowi, który ujawnił szereg nadużyć w swojej jednostce, sfabrykowano zarzuty o korzystanie z pornografii dziecięcej i treści zoofilskich w internecie. Pracownica, która ujawniła nieprawidłowości w firmie farmaceutycznej, sama została oskarżona o produkcję amfetaminy na bazie wykradanej z zakładu substancji. W ekstremalnych przypadkach podejmowano także próby zastraszenia sygnalistów groźba użycia przemocy fizycznej.

Trudno więc się dziwić, że dla części osób decydujących się na ujawnienie nadużyć było to doświadczenie prawdziwie traumatyczne, które odcisnęło piętno na całym ich życiu zawodowym, społecznym i rodzinnym. Cena odwagi cywilnej w niektórych przypadkach okazywała się drastycznie wysoka, tym bardziej że sygnaliści rzadko kiedy mogli liczyć na poczucie choćby moralnego zwycięstwa. W kilku spośród opisywanych przypadków osoby odpowiedzialne za nadużycia nie poniosły żadnych konsekwencji.

\section{$* * *$}

Jak pokazują powyższe rozważania, ujawnianie nieprawidłowości z punktu widzenia doświadczeń sygnalisty w wielu przypadkach może być poczytane jako działanie straceńcze. Organizacje, w których nadużycia kwitną za cichym przyzwoleniem kierownictwa, maja bardzo nikłe szanse na oczyszczenie się za sprawą nawet najbardziej odważnej i zdeterminowanej jednostki. Nie zmienia to faktu, że z punktu widzenia interesu publicznego whistleblowing przynosi niezaprzeczalne korzyści i jest często jedynym instrumentem zwalczania patologii godzących w istotne dobra obywateli czy konsumentów. Perspektywicznie warto jednak podkreślać konieczność budowania takich standardów zarządzania organizacjami, aby były one zdolne do wychwytywania sygnałów o nieprawidłowościach na wczesnym etapie i wdrażania działań naprawczych. Dojrzałe i świadome etycznie instytucje i firmy rozwijaja instrumenty, które pozwalaja zebrać informacje o wewnętrznych nieprawidłowościach od pracowników, starając się zminimalizować potencjalne ryzyko osobiste poniesione przez informatorów. Dlatego coraz większa popularność zyskują tzw. bezpieczne kanały informowania, zakładające możliwość anonimowego przekazania zgłoszenia. Nie ma jednak wątpliwości, że nawet najbardziej skuteczne mechanizmy 
nie zlikwiduja całkowicie kontrowersji związanych z whistleblowingiem oraz potencjalnych zagrożeń dla sygnalisty, co możemy obserwować w krajach posiadających bardzo zaawansowane systemy ochrony whistleblowers. Osoby informujące o nieprawidłowościach w organizacjach zawsze będą musiały się wykazać przede wszystkim dużą dozą nonkonformizmu i odwagi cywilnej, aby rzucić wyzwanie swemu środowisku zawodowemu i przełamać zmowę milczenia wokół nadużyć.

Bibliografia:

/// Alford C. 2001. Whistleblowers: Broken Lives and Organizational Power, Cornell University Press.

/// Association of Certified Fraud Examiners 2008. Report to the Nation on Occupational Fraud and Abuse, http://www.acfe.com/uploadedFiles/ACFE_ Website/Content/documents/2008-rttn.pdf; dostęp: 23.09.2014.

/// Calland R., Dehn G. 2004. Whistleblowing Around the World; Law, Culture and Practice, Public Concern at Work.

/// De Maria W., Jan C. 1997. Eating its Own. The Whistleblower's Organization in Vendetta Mode, „Australian Journal of Social Issues”, nr 32(1), s. 37-59.

/// Elliston F.A. 1982. Civil Disobedience and Whistleblowing. A Comparative Analysis of Two Forms of Dissent, ,Journal of Business Ethics", nr 1(1), s. 23-28.

/// Grant C. 2002. Whistle Blowers. Saints of Secular Culture, ,Journal of Business Ethics", nr 39(4), s. 391-399.

/// Jubb P.B. 1999. Whistleblowing: A Restrictive Definition and Interpretation, „Journal of Business Ethics”, nr 21(1), s. 77-94.

/// Kurczewski J. 2013. Sorokina teoria džiałań pozytymmych, „Normy, dewiacje i kontrola społeczna", t. 14.

/// Kobylińska A., Folta M. 2015. Sygnaliści-ludzie, którzy nie potrafia milcréć. Doświadczenia osób ujawniajacych nieprawidtowości w instytucjach i firmach w Polsce, Instytut Spraw Publicznych.

/// Kwaśniewski J. 1976. Pozytywna dewiacja społeczna, „Studia Socjologiczne", nr 3(62), s. 215-233. 
/// Lewicka-Strzałecka A. 2012. Whistleblowing w Polsce - dįiałanie w dobrej wierze czy donosicielstwo?, [w:] Centralne Biuro Antykorupcyjne, Mapa korupcji. Stan przestepczości korupcyjnej w Polsce w 2011 r., Wydawnictwo Centrum Szkolenia Policji, s. 21-26.

/// Merton R.K. 2002. Teoria socjologiczna i struktura społeczna, tłum. E. Morawska, J. Wertenstein-Żuławski, Wydawnictwo Naukowe PWN.

/// PwC. 2014. Global Economic Crime Survey 2014.

/// PwC Investigation and Forensic Services. 2007. Economic crime. People, culture and controls. The 4th biennial Global Economic Crime Survey.

/// Soeken D.R. 2014. Don't Kill the Messenger. How America's Valiant Whistleblowers Risk. Everything in Order to Speak Out Against Waste, Frand and Abuse in Business and Government, CreateSpace Independent Publishing Platform.

/// Swedberg R. 1999. Civil Courage (,Zivilcourage”). The Case of Knut Wicksell, „Theory and Society”, nr 28(4), s. 501-528.

/// Vandekerckhove W., James C., West F. 2013. Whistleblowing. The inside story - a study of the experiences of 1,000 whistleblowers, Project Report. Public Concern at Work.

/// Worth M. 2013. Whistleblowing in Europe. Legal Protections for Whistleblowers in the EU, Transparency International.

/// Wright K. 2008. Towards a Cultural Sociology of Whistleblowing, http://www. tasa.org.au/uploads/2011/05/Wright-Katie-Session-80-PDF.pdf; dostęp: 23.09.2014.

/// Znaniecki F. 2001. Ludzie teraźniejsi a cywilizacja przysz̧łości, Wydawnictwo Naukowe PWN.

\section{/// Abstrakt}

Whistleblowing - ujawnianie przez pracownika nieprawidłowości, do jakich dochodzi w organizacji - jest jednym z ważnych mechanizmów eliminowania patologii z instytucji publicznych i przedsiębiorstw. Artykuł podejmuje próbę odpowiedzi na pytania, czym jest whistleblowing oraz jakie jest jego społeczne znaczenie. W tekście zasygnalizowane zostały kluczowe problemy związane z ujawnianiem nieprawidłowości oraz ze społecznymi reakcjami na działalność sygnalistów. Punktem odniesienia są Mertonow- 
skie rozważania na temat nonkonformizmu oraz koncepcja pozytywnej dewiacji społecznej. Tekst odwołuje się do przykładów doświadczeń polskich sygnalistów z ostatnich lat.

Słowa kluczowe:

whistleblowing, whistleblower, nonkonformizm, pozytywna dewiacja

\section{/// Abstract}

Whistleblowing, which is the disclosure by an employee of irregularities occurring in their organization, plays a vital role in combatting wrongdoings in public institutions and business. The article discusses the key questions relating to whistleblowing and its social significance. It indicates the crucial problems connected with the disclosure of irregularities and social reactions to whistleblowing. The article refers to R.K. Merton's concept of non-conformity and to the positive social deviance theory. The issues discussed are illustrated by recent Polish examples of whistleblowing.

Keywords:

whistleblowing, whistleblower, non-conformity, positive deviance 